\title{
Finding the Gaps between ENGlish SKILls NeEded IN the IT SPECIALISTS' EMPLOYABILITY (DEMAND SIDES) AND Higher EDUCATION INSTITUTIONS (SUPPLY SIDES) IN INDUSTRY 4.0 ERA IN INDONESIA: A CONCEPTUAL FRAMEWORK
}

\author{
Rahmatika Dewi* \\ Graduate School of Humanities and Social Sciences, Division of Educational Sciences, International Education \\ Development Program \\ Hiroshima University \\ Japan \\ rahmatikadw02@gmail.com \\ *Corresponding Author email: rahmatikadw02@gmail.com
}

Submission: 20 November 2020 Revised: 24 December 2020

Accepted: 19 January 2021

Peer-review under responsibility of 6th Asia International Conference 2020 (Online) Scientific Committee

http://connectingasia.org/scientific-committee/

(C) 2021 Published by Readers Insight Publisher, Office \# 6, First Floor, A \& K Plaza, Near D Watson, F-70 Markaz, Islamabad. Pakistan, 


\section{A B S T R A C T}

Nowadays, there is a phenomenon of the increasing number of IT specialists as the effect of Industry 4.0 in many countries. This phenomenon also happens in Indonesia currently. Therefore, companies demand qualified IT specialists' human resources. However, it is questionable whether Higher Education Institutions (hereinafter, HEIs) could provide qualified IT specialists who have good IT skills or competencies as well as English skills. This study proposes a conceptual framework for doing research to find the gaps between the English materials taught in the HEls and the specific English required practically on the IT specialists' workplace.

Keywords: IT specialists' Employability, English Skills, Demand Sides, Supply Sides, HEls

\section{R E S E A R C H H I G H L I G H T S}

The research focus taken for this study is English skills considering that English is still an international language that is used for communication around the world. In addition, it was generally known that most computer products are from western coutries that use English as well as the syntaxes in programming languages used by IT specialists especially programmers in creating technologies are also written in English. Some IT documentations/manuals/FAQs provided on some websites or on online IT forums like Stackoverflow or Github are also in English.

\section{Research Objectives}

The aim of this study is to create a conceptual framework for the study about investigating the gaps between the English skills required in IT specialists' workplace and the English materials taught in the HEls.

\section{Methodology}

Since the aim of this study is to create a conceptual framework for being a path of another study so it utilizes a conceptual framework structure. Adom, Hussein, \& Agyem (2018) pointed out that a conceptual framework is the tool utilized by the investigator to illustrate the way in investigating the problems of the research. In order to design the conceptual framework, the author needs some literatures such as about IT specialists' jobs, industry 4.0 including its history, required or necessary skills to perform in industry 4.0 era, industry 4.0 phenomenon in Indonesia, potential impact of industry 4.0 for IT specialists' employment in Indonesia. some other literatures about English skills needed on workplaces, Indonesian HEls including types of HEls in Indonesia, curriculum in Indonesian HEls, Industry 4.0 and challenges for HEls in Indonesia, English language teaching in Indonesian HEls including English for general purposes and English for specific purposes are also taken as the consideration to create that conceptual framework. 


\section{Results}

The result of this study is the generated conceptual framework that is utilized for the study about the gaps between the English skills required in IT specialists' workplace and the English materials taught in the HEls. That conceptual framework is presented on the following finding part.

\section{Findings}

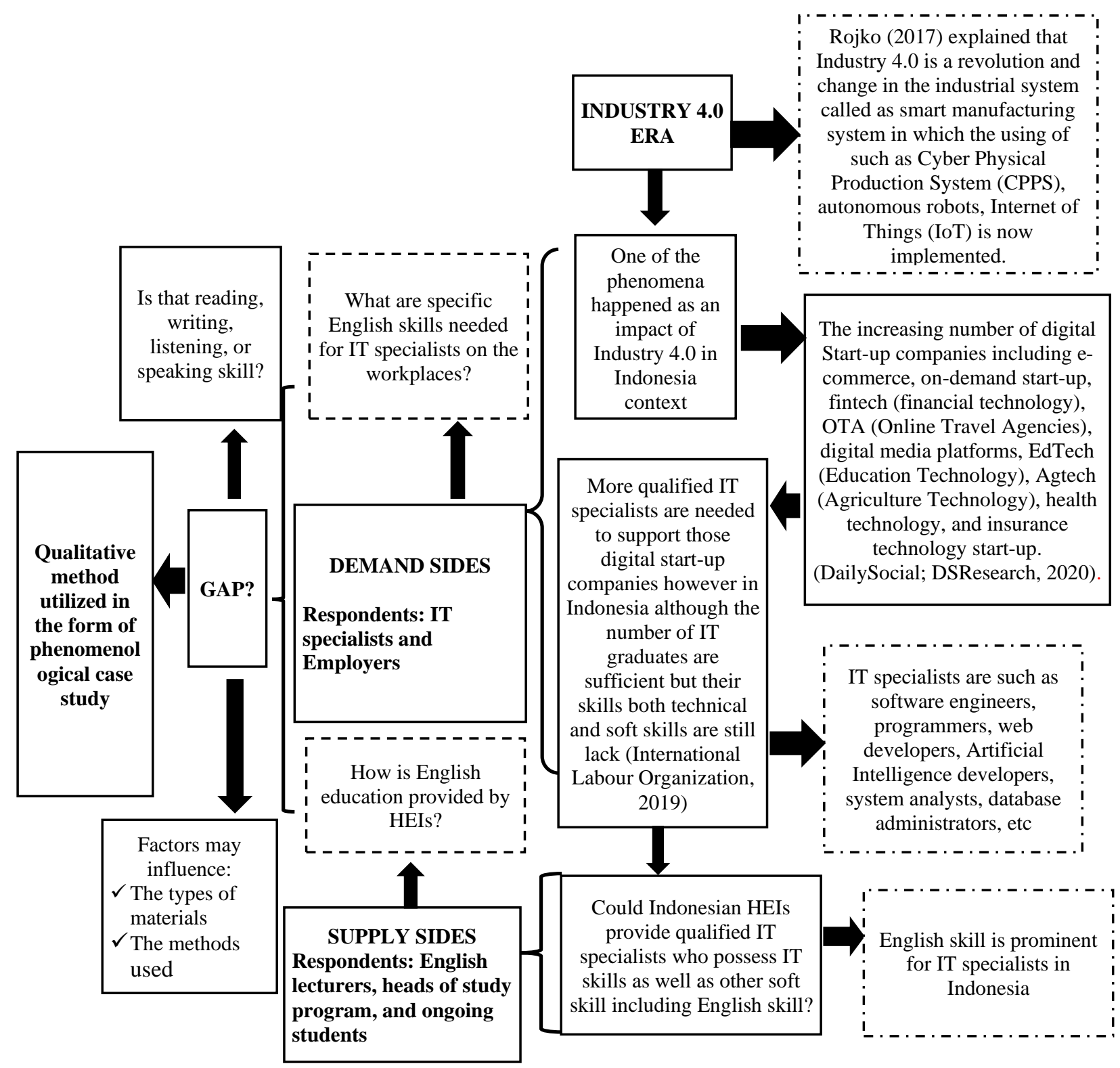

Fig. 1. The Generated Conceptual Framework

\section{References}

Adom, D., Hussein E.K., \& Agyem, J.A. (2018). Theoretical and Conceptual Framework: Mandatory Ingredients of a Quality Research. International Journal of Scientific Research, 7(1), 438-441 
Badan Pusat Statistik. (2020). Statistik Pertumbuhan Ekonomi Indonesia Triwulan I-2020. In Pertumbuhan Ekonomi Indonesia Triwulan IV-2019 (Issue 17). Badan Pusat Statistik. https://www.bps.go.id/pressrelease/2020/02/05/1755/ekonomi-indonesia2019-tumbuh-5-02-persen.html

Daily Social; DSResearch. (2020). Scaling Through Technology Democratization: Startup Report 2019 (Issue March). DailySocial.

International Labour Organization. (2019). Skills shortages and labour migration in the field of information and communication technology in India, Indonesia and Thailand. https://www.ilo.org/sector/Resources/publications/WCMS_710031/lang-en/index.htm

Rojko, A. (2017). Industry 4.0 concept: Background and overview. International Journal of Interactive Mobile Technologies, 17(5), 77-90. https://doi.org/10.3991/ijim.v11i5.7072

\section{Author's Biography}

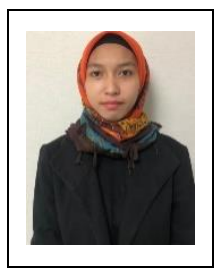

Rahmatika Dewi, S.Pd., M.Pd., M.Ed is a doctoral student of Graduate School of Humanities and Social Sciences, Division of Educational Sciences, International Education Development Program, Hiroshima University, Japan. She is also a lecturer in Politeknik Harapan Bersama in Tegal, Central Java, Indonesia. Her research interests are related to Higher Education Institutions (HEIs) to work transition, skills gap between HEls and workplace, and HEIS Curriculum Reforms. 